Pesq. Vet. Bras. 36(5):401-404, maio 2016 DOI: 10.1590/S0100-736X2016000500008

\title{
Transmission, serologic and tissue responses in chickens vaccinated with Mycoplasma gallisepticum F strain (MG-F) ${ }^{1}$
}

\author{
Leandro S. Machado ${ }^{2 *}$, Felipe F. dos Santos², Lídia M.M. dos Santos², Rogério \\ Tortelly $^{2}$, Jorge C. Pimentel ${ }^{3}$, Luiz Sesti ${ }^{3}$, Virgínia L.A. Pereira ${ }^{2}$ \\ and Elmiro R. Nascimento ${ }^{2}$
}

\begin{abstract}
Machado L.S., Santos F.F., Santos L.M.M., Tortelly R., Pimentel J.C., Sesti L., Pereira V.L.A. \& Nascimento E.R. 2016. Transmission, serologic and tissue responses in chickens vaccinated with Mycoplasma gallisepticum F strain (MG-F). Pesquisa Veterinária Brasileira 36(5):401-404. Departamento de Medicina Veterinária Preventiva e Saúde Pública, Faculdade de Veterinária, Universidade Federal Fluminense, Rua Dr. Vital Brazil Filho 64, Vital Brazil, Niterói, RJ 24230-340, Brazil. E-mail: elmiro@vm.uff.br

MG-F protects chickens from MG Mycoplasmosis and monitoring is done by serology (SAR and ELISA) and PCR. Histopathology is used to evaluate bird response to MG. This study evaluated MG-F profile vaccination in SPF chicken. This trial used 100 chickens, being 40 unvaccinated (G1), 40 eye-drop vaccinated at 8 weeks of age with MG-F ( Ceva Animal Health, São Paulo , SP , Brazil ) (G2) and 20 immunized by contact (G3) . Samples were obtained on the 8th, 12th, 15th, 18th, 20th and 24th week for SAR, ELISA and PCR. Fragments of trachea and air sac, for microscopy, were got after necropsies on the 15th and 24th week. Up to 12 weeks there was no significant difference among groups by SAR. SAR reactions appeared from the 15th week with these averages: G1 $(1.7,1.76,0.1,0.15), \mathrm{G} 2(7.81,7.65,8.25,6.29)$ and G3 $(8.1,8.5,9.5,6.16)$, while by ELISA it occurred after the $18^{\text {th }}$ week with optical densities averages: G1 $(0.19,0.14,0.16)$, G2 $(0.47,0.45,0.41)$ and G3 $(0.55,0.51,0.51)$. Positivity in G3 by PCR occurred seven weeks after exposure. At the 15 th week the air sac score means were $0.20,0.55$, and 0.32 and 24 th week were $0.15,0.80$ and 0.66 ( $p>0.05)$. For trachea, G2 (0.48) yielded higher score average than G1 $(0.10)$ and G3 $(0.00)$ on the 15 th week. Changes in G3 were seen only at 24 th week, being this average $(1.00)$ significantly different $(p<0,05)$ from G1 (0.08) and G2 (0.46). SAR and PCR detected MG-F in G3 earlier than ELISA. Higher tracheal changes for G2 and G3 as compared to G1 could be ascribed to MG-F vaccine infection.

INDEX TERMS: Mycoplasma gallisepticum F strain, MG-F, transmissibility, serology, PCR, histophatology.
\end{abstract}

RESUMO.- [Transmissão, resposta sorológica e tecidual de poedeiras vacinadas com Mycoplasma gallisepticum cepa F.] Mycoplasma gallisepticum cepa F (MG-F) é altamente utilizada em vacinação de poedeiras. MG-F confere bons níveis de proteção às galinhas, deslocando MG de campo ou diminuindo o número deles no trato respiratório. Soroaglu-

\footnotetext{
${ }^{1}$ Received on July 1, 2015.

Accepted for publication on March 15, 2016.

${ }^{2}$ Departamento de Saúde Coletiva Veterinária e Saúde Pública, Faculdade de Veterinária, Universidade Federal Fluminense (UFF), Rua Dr. Vital Brazil Filho 64, Vital Brazil, Niterói, RJ 24230-340, Brazil. E-mails: felipefaccini@hotmail.com, l_msantos@yahoo.com.br, rtortelly@hotmail.com, virginialeo@id.uff.br, elmiro@vm.uff.br, *Corresponding author: leandromachadovet@yahoo.com.br

${ }^{3}$ Ceva Saúde Animal Ltda, Rua Manoel Joaquim Filho 303, Paulínia, SP 13148-115, Brazil. E-mails: Jorge.pimentel@ceva.com, luiz.sesti@gmail.com
}

tinação Rápida (SAR), ELISA e PCR são testes no monitoramento da micoplasmose, enquanto a histopatologia, mesmo não sendo rotineira, é usada para avaliar a resposta das aves à infecção por MG. 0 objetivo deste estudo foi avaliar a transmissibilidade, soroconversão e alterações teciduais de MG-F em galinhas. Um total de 100 galinhas SPF foi utilizado, sendo 40 delas não vacinadas (G1), 40 vacinadas na $8^{\underline{a}}$ semana de idade com MG-F (Ceva Saúde Animal, São Paulo/ SP, Brasil) (G2) e 20 imunizadas por contato com aves do G2 (G3). Soros e suabes traqueais foram obtidos na $8^{\mathrm{a}}, 12^{\mathrm{a}}, 15^{\mathrm{a}}$, $18^{\mathrm{a}}, 20^{\mathrm{a}}, 24^{\mathrm{a}}$ semana para monitoramento por SAR, ELISA e PCR. Fragmentos de traqueia e saco aéreo, para microscopia, foram feitas após necropsias na $15^{\underline{a}}$ e $24^{a}$ semana. Até a $12^{\text {a }}$ semana não houve diferença significativa entre os grupos pela SAR. Houve reação a SAR a partir da $15^{\text {a }}$ semana com as seguintes médias: G1 $(1,7 ; 1,76 ; 0,1 ; 0,15)$, G2 
$(7,81 ; 7,65 ; 8,25 ; 6,29)$ e G3 $(8,1 ; 8,5 ; 9,5 ; 6,16)$, enquanto por ELISA a soroconversão ocorreu a partir da $18^{\underline{a}}$ semana com médias de densidades óticas de G1 $(0,19 ; 0,14 ; 0,16)$, G2 $(0,47 ; 0,45 ; 0,41)$ e G3 $(0,55 ; 0,51 ; 0,51)$. Todas as aves do G3 apresentaram positividade pela PCR sete semanas após exposição. Não houve diferença significativa entre as medias dos escores de saco aéreo entre os grupos, na $15^{\text {a }}$ semana $(0,20 ; 0,55 ; 0,32)$ e $24^{\underline{a}}$ semana $(0,15 ; 0,80$ e 0,66$)$. Em relação à traqueia, G2 apresentou média maior na $15^{\mathrm{a}}$ semana $(0,48)$ que G3 $(0,00)$ e G1 $(0,10)$. Alterações em G3 foram observadas somente na $24^{\mathrm{a}}$ semana onde as médias foram de 0,08(G1); 0,46 (G2) e 1,00 (G3), havendo significância $(p<0,05)$ entre G1 e G3. SAR e PCR foram capazes de detectar a transmissão de MG-F de forma precoce em relação ao ELISA. Em relação ao G1 (controle negativo) as reações teciduais para os grupos vacinados foram mais intensas na $24^{\underline{a}}$ semana, o que tudo indica sendo resposta à vacinação.

TERMOS DE INDEXAÇÃO: Mycoplasma gallisepticum cepa F, MG-F, transmissão, sorologia, PCR, histopatologia.

\section{INTRODUCTION}

Mycoplasma gallisepticum (MG) is a highly infectious respiratory pathogen that affects poultry. MG infection causes respiratory rales, nasal discharge, coughing, and occasionally conjunctivitis in chickens. The most prominent pathological findings include inflammatory lesions in trachea, air sacs, lungs, conjunctiva, and other tissues such as the oviduct (Charlton et al. 1996, Levisohn et al. 2000). Significant economic losses from $M G$ infection in poultry occur due to reduced egg production and hatchability, as well as downgrading of carcasses (Charlton et al. 1996). MG transmission can occur both horizontally through aerosols and vertically through the egg, leading to a rapid spread within the flock (Nascimento \& Pereira 2009).

Serological examinations, culturing, polymerase chain reaction (PCR) and immunohistochemical methods are used in the diagnosis of mycoplasma infections (Nascimento \& Pereira 2009). In spite of not using frequently, gross and microscopic examinations have been utilized to help the diagnosis of avian mycoplasmosis in naturally infected birds and are similar to the lesions described in experimentally infected birds (Yoder Jr 1991, Ley \& Yoder 1997).

Control of pathogenic avian mycoplasmas can consist of one of three general approaches: Maintaining flocks free of infection, medication, or vaccination. Maintaining flocks free of pathogenic mycoplasmas consists of getting replacements from mycoplasma-free sources in a single-age, all-in all-out management system. Good biosecurity and an effective monitoring system are necessary aspects of this program. Medication can be very useful in preventing clinical signs and lesions, as well as economic losses, but cannot be used to eliminate infection from a flock and is therefore not a satisfactory long-term solution. Vaccination against Mycoplasma gallisepticum (MG) can be a useful long-term solution in situations where maintaining flocks free of infection is not feasible, especially on multi-age commercial sites. Previously, bacterins and live vaccines have been used commercially for the control of M. gallisepticum infection in chickens. Killed whole-cell M. gallisepticum bacterins reduced the severity of lesions and egg production losses but did not completely prevent $M$. gallisepticum colonization of the chicken respiratory tract upon challenge (Kleven 1986, Yagihashi 1986). At the same time, bacterins fail to provide complete protection against heterologous exposure. Over the past decade, the use of bacterins has been supplanted by more effective live attenuated vaccines.

Attenuated vaccines stimulate immune responses by cellular and humoral basis and act as an instrument of competitive exclusion in relation to field MG strains (Cummings \& Kleven 1986, Whithear 1996). There are four live MG vaccine types available, i.e., F-Conn strain (MG-F), ts-11, 6/85 and MG-70 which can reduce drop in egg production, although they are not able to prevent transovarial transmission (Carpenter et al. 1981, Glisson \& Kleven 1984). The ts-11 and 6/85 strains induced a milder post-vaccination reaction than F-strain, produced a weaker serological response, and did not persist as long in the upper respiratory tract. The F-strain-vaccinated chickens had the fewest and mildest air-sac lesions post-challenge, the 6/85 and ts-11 groups had somewhat less protection against airsacculitis (Abd-El-Motelib \& Kleven 1993).

The aim of this study was to evaluated MG-F profile vaccination (transmission to contact birds, serologic and tissue responses in trachea and air sac of SPF chicken.

\section{MATERIALS AND METHODS}

Pullet housing and management. This experiment was conducted in premises located in Cachoeiras of Macacu-RJ, Brazil, starting with 100 1-day-old chicks from SPF eggs hatched on site. During the experiment, the birds were housed in isoleted experimental room units. The rooms measured $3 \times 3 \mathrm{~m}$, with roof clay and millimeter screens on window and door and Polyvinyl chloride (PVC) lining under the roof. Feed and water were provided ad libitum throughout the experimental period by the use of tubular feeders and bell-shaped drinkers. The feed formulation followed the nutritional requirements of each stage of rearing, with natural day light. The experiment was authorized by the permission number 155 from the Animal Care Ethic Committee of the Fluminense Federal University, Niterói/RJ, Brazil.

Experimental design. A total of 100 leghorn chickens were used, being 40 unvaccinated (Group 1), 40 eye-drop vaccinated at 8 weeks of age with MG - F (Ceva Animal Health, São Paulo, SP, Brazil) (Group 2) and 20 immunized by contact (Group 3).

Serology. Blood samples for serum obtention were collected at $8,12,15,20,24,27,30$ and 33 weeks of age for SAR and Elisa serology. Approximately $3.0 \mathrm{~mL}$ of blood were collected from the brachial vein of each bird. The sera obtained were immediately tested for SAR against MG antigens according to the manufacturer's instructions (Intervet, SP, Brazil). Undiluted positive sera by SAR were considered suspicious and were therefore diluted further and retested. Serum was considered positive if the positivity was seen at a dilution of 1:10, according to the guidelines of the National Poultry Health (National Poultry Health Program, PNSA, Brasil, 1994). Sera received the following scores: negative gross serum $(0)$, diluted serum positive (1) positive serum dilution 1:5 (5) and positive serum at 1:10 dilution (10). The variation of the intensity of the reaction was investigated by analysis of variance (ANOVA).

MG ELISA was analised by M. gallisepticum Antibody Test Kit (IDEXX, SP, Brazil). The results obtained were considered positive when the optical density (OD) was equal to or greater than 0.2 . 
Necropsy. Chickens were euthanized and necropsied at the 15 th and 24th week of age by cervical dislocation according to the resolution number 1000 of the Veterinary Medicine Federal Council (CFMV). Samples from tracheas and air sacs were analised from gross examination and fixed in $10 \%$ neutral buffered formalin and submitted for histological analysis. These tissues were routinely processed, embedded in paraffin, sectioned, mounted on glass slides, and stained with hematoxylin and eosin according to standard histological protocols. Sections of trachea and air sacs were examined microscopically. Tracheal lymphocytic infiltrates and air sac were scored using the system of Nunoya et al. (1987) (24) and Papazisi et al. (2002) with minor modifications (27).

Airsac lesion score. Airsac lesion scores were grossly evaluated according to the following criteria: 0: normal air sac, clear and thin; 1 = slightly claudy and/or dark with slight thickening; 2 = medium turbidity and/or with yelloow exsudate, often foamy; 3 = severe exsudation and thickening; 4 = severe airsacculitis with considerable exudates. By airsac microscopy, the scores were: 0: no changes; 1 : discrete nodular lesion with few heterophilis; 2 : nodular lesion with infiltration of heterophilis; 3: diffuse nodular lesions with heterophilis.

Tracheal lesion score. Trachea were grossly examined and lesions were graded by the following scores: 0 : Normal; 1 : hiperemic or petequiae, often some mucous; 2 : enough mucous present; 3 : mucous im excess; 4: mucous in excess and thickening. By tracheal microscopy scoring were: 0: no lesion; 1: 1-3 discrete lymphoid aggregates (DLA) without submucosa invasion or at least one of them invading the submucosa, or four or more ALD with or without invasion of the submucosa; 2: DLA (regardless of the number and the invasion of the submucosa) associated with one or two lymphoid aggregates in follicular pattern (LAFP) without scattering to the lamina propria; 3: DLA (regardless of the number and the invasion of the submucosa) associated with one or two LAFP with submucosa invasion; and/or discrete confluence among focus and / or follicles; 4: DLA (regardless of the number and the invasion of the submucosa) associated with three or more LAFP with submucosa invasion with or without invasion of the submucosa and / or extensive diffuse infiltration of the lamina propria independent of submucosa invasion.The variation of the degree of lesions by group was investigated by analysis of variance (ANOVA).

PCR. Tracheal swabs were collected at the 8th, 12th, 15th, 18th, 20th and 24th week and stored in $1 \mathrm{ml}$ of medium Frey. Each swab sample was then packaged in graduated tubes of $1.5 \mathrm{ml}$ and had their DNA extracted by the phenol -chloroform adapted from
Sambrook et al. (1989), without pre-enrichment. The quantification of DNA was performed using the spectrophotometer Biodrop Touch $^{\circledR}$ (Biochrom) with values around 25-30ng/ul.

The pair of "primers" and amplification conditions for MG-F PCR followed Nascimento et al. (1993). As a positive control we used the MG - F vaccine (Ceva Animal Health, São Paulo, SP, Brazil). The PCR for MG - F was performed under the following conditions: $56 \mu \mathrm{L}$ of ultrapure water (Milli - Q), $10 \mu \mathrm{L}$ of 10X PCR buffer, $8 \mu \mathrm{L} \mathrm{MgCl} 2$ (25 mM), dNTP mix $5 \mu \mathrm{L}(0.25 \mathrm{mM}$ each), $2 \mu \mathrm{L}$ $(100 \mathrm{pmol})$ of each " primer " (5'CGT GGA TAT CTT TTC TAG CAG CTG GCA C3'e 5'GTA AGT TAT CAG GCA AAT TTC T3'), $2 \mu \mathrm{L}$ (2.5 U/ $\mu \mathrm{L}$ ) of Taq Polymerase and $15 \mu \mathrm{L}$ DNA extracted to yield a final volume of $100 \mu \mathrm{L}$. After amplification reaction, $10 \mu \mathrm{L}$ of each sample were homogenized with $2 \mu \mathrm{L}$ of buffer and applied in $1.5 \%$ agarose gel submerged in Tris- Borate- EDTA (TBE) 0.5X, and finally uploaded to the electrophoresis conditions based on Sambrook et al. (1989). After electrophoresis, the gel was stained in ethidium bromide and proceeded to display the "amplicons" of 524 base pairs under ultraviolet light transilluminator.

\section{RESULTS AND DISCUSSION}

At the 8th week of age, blood samples from the chickens were negative for Mycoplasma gallisepticum (MG) by SAR and ELISA, being the score averages by SAR of 0 and optical density (OD) averages of $0.163 ; 0.172$ and 0.172 for groups 1,2 and 3 respectively. Tracheal swabs collected at the 8th and 12th week were negative for MG-F PCR (Fig.1).

Up to 12 weeks there was no significant difference among groups by SAR and ELISA (Kruskal-Wallis test, $\mathrm{p}>0.05)$. SAR reactions appeared from the $15 \mathrm{t}^{\mathrm{h}}$ week in G2 and G3 (Tukey-Kramer, $\mathrm{p}<0,05$ ) while by ELISA it occurred in the $18^{\text {th }}$ week (Tukey-Kramer, $\mathrm{p}<0.05$ ) (Table 1 and 2). Positivity in G3 by PCR occurred seven weeks after exposure and in the 15th week all contact birds were positive by PCR (Fig.1) and SAR, agreed with Kleven et al. (1981) and Avakian et al. (1988) wich concluded that MG infection was transmitted during the first 4 weeks postinfection. Furthermore, AvaKian et al. (1988) proved that SAR as more sensitive than ELISA and HI test during three weeks postinfection. Pakpinyo et al. (2013) detected vaccine MG-F by SAR and PCR in all birds six weeks post vaccination, ELISA's reactions were present but appear in fewer layers.

Table 1. ELISA serologic response in OD for MG-F in chickens unvaccinated (G1), vaccinated at $8^{\text {th }}$ weeks of age (G2) and vaccinated by contact (G3) according to age in weeks

\begin{tabular}{cccccc}
\hline Groups & 12 th $^{*}$ & 15 th $^{* *}$ & 18 th $^{* *}$ & 20 th $^{* *}$ & 24 th $^{* *}$ week \\
\hline 1 & $0,1551 \pm 0,013^{\mathrm{a}}$ & $0,1551 \pm 0,013^{\mathrm{a}}$ & $0,1867 \pm 0,028^{\mathrm{a}}$ & $0,1428 \pm 0,06^{\mathrm{a}}$ & $0,1564 \pm 0,061^{\mathrm{a}}$ \\
2 & $0,151 \pm 0,0312^{\mathrm{a}}$ & $0,189 \pm 0,079^{\mathrm{b}}$ & $0,4695 \pm 0,2095^{\mathrm{b}}$ & $0,455 \pm 0,203^{\mathrm{b}}$ & $0,414 \pm 0,1871^{\mathrm{b}}$ \\
3 & $0,146 \pm 0,0189^{\mathrm{a}}$ & $0,129 \pm 0,034^{\mathrm{b}}$ & $0,555 \pm 0,2085^{\mathrm{b}}$ & $0,509 \pm 0,207^{\mathrm{b}}$ & $0,508 \pm 0,1904^{\mathrm{b}}$
\end{tabular}

*ANOVA/ Kruskal-Wallis $\mathrm{p}<0,05$; ${ }^{\mathrm{a}, \mathrm{b}}$ different letters on the same column means significant differences. ** ANOVA/ Tukey-Kramer.

Table 2. Response by SAR for in chickens unvaccinated (G1), vaccinated at $8^{\text {th }}$ weeks of age (G2) and vaccinated by contact (G3) according to age in weeks

\begin{tabular}{cccccc}
\hline Groups & 12 th $^{*}$ & 15 th $^{* *}$ & 18 th $^{* *}$ & 20 th $^{* *}$ & 24 th $^{* *}$ week \\
\hline 1 & $0,05 \pm 0,2357^{\mathrm{a}}$ & $0,17 \pm 2,95^{\mathrm{a}}$ & $1,76 \pm 2,873^{\mathrm{a}}$ & $0,1 \pm 0,3162^{\mathrm{a}}$ & $0,15 \pm 0,366^{\mathrm{a}}$ \\
2 & $4,968 \pm 3,361^{\mathrm{a}}$ & $7,81 \pm 3,69^{\mathrm{b}}$ & $7,65 \pm 3,498^{\mathrm{b}}$ & $8,25 \pm 0,2447^{\mathrm{b}}$ & $6,29 \pm 3,667^{\mathrm{b}}$ \\
3 & $0,05 \pm 0,2236^{\mathrm{b}}$ & $8,1 \pm 3,25^{\mathrm{b}}$ & $8,5 \pm 2,415^{\mathrm{b}}$ & $9,5 \pm 1,581^{\mathrm{b}}$ & $6,16 \pm 4,446^{\mathrm{b}}$
\end{tabular}

${ }^{*}$ ANOVA/Kruskal-Wallis $\mathrm{p}<0.05$; ${ }^{\mathrm{a}, \mathrm{b}}$ different letters on the same column means significant differences.

** ANOVA/Tukey-Kramer. 


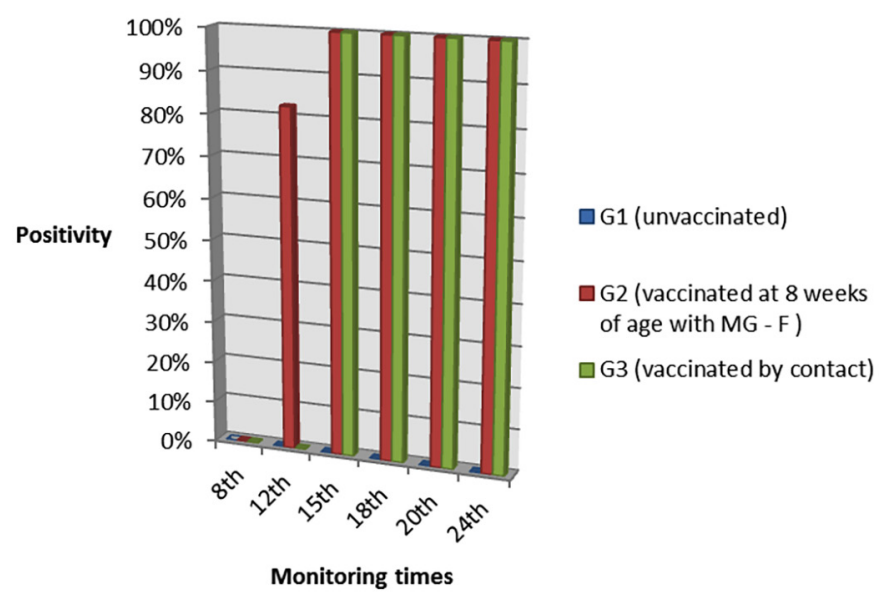

Fig.1. Experimental chickens positivity percentage by PCR at monitoring times in unvaccinated, eight week vaccinated and contact groups.

Table 3. Mean scores of gross lesions (M) and microscopic (m) in tracheas and air sacs in chickens no vaccinated (G1), vaccinated (G2) and vaccinated by contact (G3) with F strain of Mycoplasma gallisepticum (MG-F), at different stages of the experiment

\begin{tabular}{|c|c|c|c|c|c|c|c|c|}
\hline \multirow[t]{3}{*}{ Vaccination } & \multicolumn{4}{|c|}{ Trachea } & \multicolumn{4}{|c|}{ Air sac } \\
\hline & \multicolumn{2}{|c|}{ 15th week } & \multicolumn{2}{|c|}{ 24th week } & \multicolumn{2}{|c|}{ 15th week } & \multicolumn{2}{|c|}{ 24th week } \\
\hline & M & $\mathrm{m}$ & M & $\mathrm{m}$ & M & $\mathrm{m}$ & M & $\mathrm{m}$ \\
\hline G1 & $0,20^{\mathrm{a}}$ & $0,1^{\mathrm{a}}$ & $0,25^{\mathrm{a}}$ & $0,07^{\mathrm{a}}$ & $0,3^{\mathrm{a}}$ & $0,2^{\mathrm{a}}$ & $0,125^{a}$ & $0,15^{\mathrm{a}}$ \\
\hline G2 & $0,6^{\mathrm{a}}$ & $0,0^{\mathrm{a}}$ & $0,64^{a}$ & $1,00^{\mathrm{a}}$ & $0,91^{\mathrm{a}}$ & $0,32^{\mathrm{a}}$ & $0,71^{\mathrm{a}}$ & $0,66^{\mathrm{b}}$ \\
\hline G3 & $0,6^{\mathrm{a}}$ & $0,4^{\mathrm{b}}$ & $0,60^{\mathrm{a}}$ & $0,46^{\mathrm{b}}$ & $0,9^{\mathrm{a}}$ & $0,55^{\mathrm{a}}$ & $0,60^{\mathrm{a}}$ & $0,80^{\mathrm{b}}$ \\
\hline
\end{tabular}

*ANOVA/Kruskal-Wallis $\mathrm{p}<0,05$; ${ }^{\mathrm{a}, \mathrm{b}}$ different letters on the same column means significant differences.

The average scores for the gross and microscopic lesions by group were obtained (Table 3). There was no significant difference between the mean scores of the gross lesions of trachea and air sac. Whereas the mean scores of microscopic tissue changes appeared in the 15 th week $(p=0.1266)$ and $24 \mathrm{th}^{\mathrm{h}}$ week $(\mathrm{p}=0.0379)$ in trachea and at $24 \mathrm{th}^{\mathrm{h}}$ week $(\mathrm{p}=0.0391)$ in air sac. Regarding trachea, G3 showed no lesions in 15th week (0.00) as compared to G1 $(0.10)$ and G2 (0.48); lesions were observed at the 24th week (1.00) compared to G1 (0.077) and G3 (0.46). Probably G3 did not have tissue changes in the $15^{\text {th }}$ week because the chicken did not receive directly the vaccination, that is, major changes occurred at the 24th week when start of local immune reactions. All birds yielded low scores throughout the experimental period, proving that MG-F was not causing significant tissue changes in the trachea and air sac. The present study agree with the reports of Levisohn et al. (1983) and Pakpinyo et al. (2013) who concluded that MG-F colonization of the tracheal tissue was accompanied by discrete changes. Pakpinyo et al. (2013) also found that MG-F caused no injuries in air sac two weeks after vaccination So the presence of low scores in this study is explained by the long time after for histopathological evaluation vaccination. Furthermore, the method of inoculation by eye drop induces less aerosaculitis than aerosol (Lin \& Kleven 1984).

\section{CONCLUSION}

SAR and PCR were able to detect the transmission of MG-F earlier than ELISA. Compared with the negative control, the tissue reactions to the vaccine groups were more intense in the 24 th week, it seems to be response to vaccination.

Acknowledgements.- To Coordenação de Aperfeiçoamento de Pessoal de Nível Superior (CAPES) and Conselho Nacional de Desenvolvimento Científico (CNPq) for financial support.

\section{REFERENCES}

Abd-El-Motelib T.Y. \& Kleven S.H. 1993. A Comparative Study of Mycoplasma gallisepticum Vaccines in Young Chickens. Avian Dis. 37(4):981-987.

Avakian A.P., Kleven S.H. \& Glisson J.R. 1988. Evaluation of the specificity and sensitivity of two commercial enzyme-linked immunosorbent assay kits, the serum plate agglutination test, and the hemagglutination-inhibition test for antibodies formed in response to Mycoplasma gallisepticum. Avian Dis. 32(2):262-272

Brasil 1994. Portaria Ministerial no 193, de 19 de setembro de 1994. Institui o Programa Nacional de Sanidade Avícola, Ministério da Agricultura e Abastecimento (MAA). Diário Oficial da República Federativa do Brasil, Brasília/DF.

Carpenter T.E., Mallinson E.T., Miller K.F., Gentry R.F. \& Schwartz L.D. 1981. Vaccination with F-strain Mycoplasma gallisepticum to reduce production losses in layer chickens. Avian Dis. 25:404-409.

Charlton B.R., Bermudez A.J., Boulianne M., Eckroade R.J., Jeffrey S., Newman L.J., Sander J.E. \& Wakenell P.S. 1996. Avian Disease Manual. American Association of Avian Pathologists, Pennsylvamia, p.115-125.

Cummings T.S. \& Kleven S.H. 1986. Evaluation of Protection against Mycoplasma gallisepticum Infection in Chickens Vaccinated with the F Strain of M. gallisepticum. Avian Dis. 30(1):169-171.

Glisson J.R. \& Kleven S.H. 1984. Mycoplasma gallisepticum Vaccination: effects on egg transmission and egg production. Avian Dis. 28(2):406-415.

Kleven S.H.1981. Transmissibility of the F strain of Mycoplasma gallisepticum in Leghorn chickens. Avian Dis. 25(4):1005-1018.

Kleven S.H. 1986. Tracheal populations of Mycoplasma gallisepticum after challenge of bacterin-vaccinated chickens. Avian Dis. 29:1013-1017.

Levisohn S. \& Kleven S.H. 2000. Avian mycoplasmosis (Mycoplasma gallisepticum). Rev. Sci. Tech. OIE 19(2):425-442.

Levisohn S., Yegana Y., Hod I. \& Herz A. 1983. A correlative in vivo study of the surface morphology and colonisation of the chicken trachea infected by Mycoplasma gallisepticum strains R and F. Avian Pathol. 12(2):247-261.

Ley D.H. \& Yoder Jr H.W. 1997. Mycoplasma gallisepticum infections, p.194207. In: Calnek B.W., Barnes H.J., Beard C.W., McDougald L.R. \& Saif Y.M. (Eds), Diseases of Poultry. 10th ed. Iowa State University Press, Ames.

Lin M.Y. \& Kleven S.H. 1984. Evaluation of attenuated strains of Mycoplasma gallisepticum as vaccines in young chickens. Avian Dis. 28:88-99.

Nascimento E.R. \& Pereira V.L.A. 2009. Micoplasmoses, p.485-500. In: Di Fabio J. \& Rossini L.I. (Eds), Doenças das Aves. FACTA, Campinas.

Nascimento E.R., Yamamoto R. \& Khan M.I. 1993. Mycoplasma gallisepticum F-vaccine strain-specific polymerase chain reaction. Avian Dis. 37(1):203-211.

Nunoya T., Tajima M., Yagihashi T. \& Sannai S. 1987. Evaluation of respiratory lesions in chickens induced by Mycoplasma gallisepticum. Jpn. J. Vet. Sci. 49:621-629.

Pakpinyo S., Wanaratana S., Sangthongdang K. \& Paniago M. 2013. Efficacy and safety of different live Mycoplasma gallisepticum vaccines in layer chickens. Thai J. Vet. Med. 43(4):533-540.

Papazisi L., Silbart L.K., Frasca Jr S., Rood D., Liao X., Gladd M., Javed M.A. \& Geary S.J. 2002. A modified live Mycoplasma gallisepticum vaccine to protect chickens from respiratory disease. Vaccine 20:3709-3719.

Sambrook K.J., Fritsch E.F. \& Maniatis T. 1989. Molecular Clonning: a laboratory manual. Vol.3. 2nd ed. Cold Spring Harbour Laboratory, New York, p.3-15.

Whithear K.G. 1996. Control of avian mycoplasmoses by vaccination. Rev. Sci. Tech. OIE 15:1527-1553.

Yagihashi T., Nunoya T. \& Tajima M. 1986. Immunity induced with aluminum hydroxide-adsorbed Mycoplasma gallisepticum bacterin in chickens. Avian Dis. 31:149-155.

Yoder Jr H.W. 1991. Mycoplasmosis, p.196-212. In: Calnek B.W., Barnes H.J., Beard C.W., Reid W.M. \& Yoder Jr H.W. (Eds), Diseases of Poultry. 9th ed. Iowa State University Press, Ames. 